Zeszyty Naukowe Szkoły Głównej Gospodarstwa Wiejskiego w Warszawie Problemy Rolnictwa Światowego tom 17 (XXXII), zeszyt 3, 2017: 286-297

DOI: $10.22630 /$ PRS.2017.17.3.74

Andrzej Piotr Wiatrak ${ }^{1}$

Uniwersytet Warszawski

\title{
Potrzeby i kierunki wspierania innowacyjności w agrobiznesie
}

\section{Needs and Directions for Supporting Innovation in Agribusiness}

\begin{abstract}
Synopsis. Celem artykułu było określenie potrzeb innowacyjnych w agrobiznesie i ich uwarunkowań oraz przewidywanych kierunków ich realizacji. Na treść artykułu składają się następujące zagadnienia: charakterystyka podstawowych pojęć z zakresu innowacyjności i ich powiązania ze sobą, potrzeby innowacyjne agrobiznesu i ich uwarunkowania, kierunki wspierania innowacyjności w agrobiznesie przez politykę Unii Europejskiej oraz kierunki wspierania innowacyjności w agrobiznesie przez politykę w Polsce. Z przeprowadzonych rozważań wynika, że innowacyjność należy rozpatrywać szeroko, biorąc pod uwagę dotychczasowy poziom innowacyjności, potrzeby w zakresie innowacji, proces innowacyjny i jego uwarunkowania oraz przyjęcia ich jako podstawy wyznaczania kierunków innowacji i polityki innowacyjnej w agrobiznesie. Artykuł przygotowano na podstawie literatury przedmiotu oraz dokumentów i materiałów dotyczących polityki innowacyjnej UE i Polski.
\end{abstract}

Slowa kluczowe: agrobiznes, proces innowacyjny, polityka innowacyjna

\begin{abstract}
Aim of this article was to identify innovative needs in agribusiness and their determinants and predicted directions of their implementation This study discusses the following issues: characteristics of basic concepts of innovation and their interrelationships, innovation needs of agribusiness and their determinants, directions of supporting innovation in agribusiness by EU policy and directions of supporting innovation in agribusiness by policy in Poland. Considerations shows that innovation should be considered broadly, taking into account the level of innovation so far, the needs for innovation, the innovation process and its conditioning and the adoption of them as a basis for setting the direction of innovation and agribusiness innovation policy. This article is based on the literature of the subject and documents and materials related to EU and Polish innovation policy.
\end{abstract}

Key words: agribusiness, innovation process, innovation policy

\section{Wprowadzenie}

W ostatnich latach wiele mówi się o innowacjach. Wynika to z różnych przyczyn. Po pierwsze jest to następstwem polityki Unii Europejskiej, która określa kierunki innowacyjnych rozwiązań. Zagadnienia te ujmują z jednej strony polityki sektorowe (np. polityka rolna, przemysłowa itd.) - wskazując na potrzeby restrukturyzacji i rozwoju, a z drugiej polityka innowacyjna - wskazując na potrzebę kompleksowego podejścia do innowacji o charakterze horyzontalnym. Po drugie wdrożenie innowacyjnych rozwiązań będzie sprzyjało poprawie sytuacji ekonomicznej i konkurencyjności gospodarki poszczególnych krajów UE, prowadząc do racjonalniejszego wykorzystania zasobów i wyboru specjalizacji. Po trzecie wdrażanie innowacji jest koniecznością ze względu na ochronę środowiska przyrodniczego i wprowadzenia technologii oszczędzających środowisko, chroniących klimat, energooszczędnych itd. I po czwarte - z potrzeb w zakresie

${ }^{1}$ prof. dr hab., Uniwersytet Warszawski, Wydział Zarządzania, Katedra Teorii Organizacji i Zarządzania, Zakład Zarządzania Publicznego, ul. Szturmowa 1/3, 02-678 Warszawa, e-mail: apw@wz.uw.edu.pl 
wdrożenia innowacji $\mathrm{w}$ wielu krajach członkowskich UE, wynikających $\mathrm{z}$ niskiego dotychczasowego poziomu unowocześnienia gospodarki. Z taką sytuacją mamy do czynienia $\mathrm{w}$ Polsce, $\mathrm{w}$ tym $\mathrm{w}$ odniesieniu do agrobiznesu.

W niniejszym artykule - biorąc pod uwagę obecne zainteresowanie się problematyką innowacji i rolę jaką ma spełniać w gospodarce - podjęto próbę ukazania uwarunkowań procesów innowacyjnych na przykładzie agrobiznesu w Polsce. Celem artykułu było z jednej strony określenie potrzeb innowacyjnych i ich uwarunkowań, a z drugiej - przewidywanych kierunków ich realizacji. Rozważania są głównie prowadzone na poziomie makroekonomicznym, z punktu widzenia całości agrobiznesu, a nie poszczególnych podmiotów. Artykuł przygotowano na podstawie literatury przedmiotu oraz dokumentów i materiałów dotyczących polityki innowacyjnej UE i Polski. Podstawą rozważań były metody przetwarzania danych, tj. analiza i synteza.

$\mathrm{Na}$ treść artykułu składają się następujące zagadnienia: charakterystyka podstawowych pojęć z zakresu innowacyjności i ich powiązania ze sobą, potrzeby innowacyjne agrobiznesu i ich uwarunkowania, kierunki wspierania innowacyjności w agrobiznesie przez politykę Unii Europejskiej oraz kierunki wspierania innowacyjności w agrobiznesie przez politykę w Polsce.

\section{Podstawowe pojęcia}

Podstawowe pojęcia, które są przedmiotem niniejszego artykułu, to innowacyjność, innowacje, proces innowacyjny, polityka innowacyjna i narzędzia wdrażania polityki innowacyjnej (Wiatrak, 2016a). Wszystkie te pojęcia są ściśle ze sobą powiązane, a czasami nawet utożsamiane - jak innowacyjność i innowacja.

Innowacyjność jest aktywną postawą ludzi, którzy są otwarci na nowe idee i rozwiązania oraz wprowadzanie ich w życie. Postawa ta przejawia się w różny sposób: otwartością na przyswojenie nowych rozwiązań, ich poszukiwaniem, czy też rozpowszechnianiem. Nowe rozwiązania mogą dotyczyć różnorodnych (wszystkich lub też wybranych) aspektów życia społeczno-gospodarczego (np. żywności), dla których poszukuje się innych, w założeniu lepszych, sposobów konsumowania i gospodarowania. Innowacyjność dotyczy zarówno konkretnej osoby, jak i grupy w organizacji lub całej organizacji oraz analogicznie: regionu, państwa itd., obejmując trzy obszary: proces technologiczny, produkt i organizację (Firlej i Makarska, 2012). Innowacyjność łączy się z takimi cechami, jak: adaptacyjność, przedsiębiorczość, dynamizm, skłonność do ryzyka itp.

Proces innowacyjny można określić jako zespół działań podejmowanych w celu powstania $\mathrm{i}$ wprowadzenia $\mathrm{w}$ życie nowych rozwiązań techniczno-technologicznych, biologiczno-technologicznych i organizacyjno-zarządczych. Proces ten jest następstwem innowacyjności, wynikającym z urzeczywistniania powstałych koncepcji i idei zmian. Przebiega on w zróżnicowany sposób, w zależności od tego, gdzie powstaje pomysł innowacji, ile kosztuje, kto go finansuje, jakie jest zainteresowanie jego wdrożeniem ze strony poszczególnych interesariuszy itd. Ujmują to zarówno klasyczne, liniowe modele innowacji - popytowy i podażowy, jak i modele bardziej złożone - interakcyjne, zintegrowane, czy łańcuchowe (Czerniak, 2013). Model procesowy innowacji można przedstawić w postaci następujących faz (Klincewicz, 2011):

Pomysły $\rightarrow$ Badania i rozwój $\rightarrow$ Wdrożenie $\rightarrow$ Komercjalizacja $\rightarrow$ Dyfuzja 

2014):

Współczesny proces innowacyjny charakteryzuje się następującymi cechami (Jasiński,

- złożoność i kompleksowość - ujmująca wielosekwencyjność procesów i ich powiązania, co wymusza współpracę i wspólne działanie w jego realizacji,

- wysoka kosztochłonność, wynikająca ze złożoności procesu innowacyjnego i powiązania $\mathrm{z}$ innymi procesami,

- fazowość - proces innowacyjny składa się z wielu etapów jego realizacji, przy czym ich liczba jest uzależniona od jego złożoności i czasu realizacji,

- wysokie ryzyko niepowodzenia, występujące w każdej fazie realizacji procesu.

Innowacja jest zastosowaniem w praktyce nowych rozwiązań (materialnych i niematerialnych) w odniesieniu do procesu, produktu (wyrobu lub usługi), marketingu lub organizacji (OECD, 2005; Klincewicz 2011). Składają się na nią z jednej strony efekty pracy badawczo-rozwojowej w organizacji i jednostkach naukowo-badawczych, prowadzanych samodzielnie lub we współpracy, a z drugiej - wynikają one z pozyskiwania wiedzy z innych organizacji, odbywające się poprzez zakupy patentów, licencji, zakupy gotowych rozwiązań produkcyjnych i organizacyjnych, zakupy nowoczesnych maszyn, urządzeń i usług związanych z ich uruchomieniem itd. Innowacje mają różny charakter. I tak ze względu na ich zastosowanie w organizacji można wyróżnić odpowiednio innowacje: procesowe, produktowe, organizacyjne i marketingowe. Dwa pierwsze rodzaje są innowacjami materialnymi, a kolejne dwa - innowacjami niematerialnymi. Podstawowe znaczenie mają innowacje materialne, ale $w$ dzisiejszych czasach rośnie znaczenie innowacji niematerialnych. Najczęściej innowacje niematerialne ściśle łączą się z innowacjami materialnymi, będąc ich uzupełnieniem, albo tez mogą przyczyniać się do uruchomienia procesu innowacyjnego (np. innowacje organizacyjne). Ponadto wdrażane innowacje mogą być innowacjami absolutnymi i względnymi, tj. odpowiednio: stosowanymi po raz pierwszy na świecie, albo stosowanymi już gdzie indziej, a po raz pierwszy w danym kraju, regionie, czy organizacji. Z kolei ze względu na wielkość wprowadzanych zmian można mówić o innowacjach imitujących, umiarkowanych i radykalnych (por. OECD, 2005, Klincewicz, 2011). Podkreślić należy, że innowacja jest następstwem innowacyjności i procesu innowacyjnego oraz działań związanych wprowadzaniem i upowszechnianiem nowych rozwiązań.

Polityka innowacyjna są celowe działania skierowane na stymulowanie procesów innowacyjnych i podejmowania ich przez organizacje. Działania te są prowadzone przez władze kraju, województwa, powiatu i gminy, ale także przez zarządzających organizacją. Wpływ na politykę innowacyjną mogą mieć organizacje międzynarodowe (np. OECD, czy MOP) i ugrupowania państw (np. UE). Zakres ich oddziaływań zmienia się w czasie, ale podstawą są zmiany i realizacja nowych rozwiązań. Zmiany polityki innowacyjnej są następstwem rozwiązywania pojawiających się problemów rozwojowych, które są formułowane przez politykę gospodarczą, sektorową, regionalną, społeczną, środowiskową, naukową i technologiczną, ale w powiązaniu $z$ osiągnięciami nauki i techniki. Polityka innowacyjna jest pojęciem złożonym, uwzględniającym różne polityki, ale jej podstawą są polityka naukowa i technologiczna. Współczesna polityka innowacyjna uwzględnia innowacje materialne i niematerialne, wspierając procesy innowacyjne w gospodarce i społeczeństwie, realizując coraz więcej celów społecznych i środowiskowych. Jednocześnie na ona coraz mniej charakter sektorowy, a coraz więcej charakter ponadsektorowy, horyzontalny (Wiatrak, 2016a). 
Narzędzia wdrażania polityki innowacyjnej, tj. środki jej realizacji, powinny być ukierunkowane na wspieranie określonych procesów innowacyjnych i określonych aktorów. W Polsce odbywa się to za pomocą następujących narzędzi (Czerniak, 2013; Jasiński, 2014):

1. Regulacje prawne, które obejmują normy, standardy, limity, zakazy, nakazy i przepisy dotyczące ochrony środowiska naturalnego, konsumenta, konkurencji oraz własności intelektualnej, określając warunki brzegowe dla działań różnych podmiotów w zakresie innowacji;

2. Instrumenty finansowe, takie jak system ulg i zwolnień podatkowych, preferencji i zachęt finansowych itp. do wprowadzania określonego rodzaju innowacji;

3. Programy oraz projekty rządowe i samorządowe, ukierunkowane na realizację konkretnych celów i zadań (np. sieć innowacji rolniczych), w tym również zamówienia publiczne, partnerstwo publiczno-prywatne;

4. Instrumenty instytucjonalne, prowadzone poprzez instytucje (np. Polską Agencję Rozwoju Przedsiębiorczości, czy też Centrum Doradztwa Rolniczego) i ukierunkowane na wsparcie podmiotów uczestniczących $\mathrm{w}$ procesach innowacyjnych, np. poprzez system edukacyjno-doradczy i prawny, pomoc $\mathrm{w}$ zawieraniu partnerstwa innowacyjnego.

Między przedstawionymi pojęciami istnieje - o czym już była mowa - ścisłe powiązanie. Istniejący poziom innowacyjności jest podstawą opracowania określonych zasad polityki innowacyjnej i instrumentów jej wdrażania, które w miarę ich upowszechniania lub powstawania nowych problemów innowacyjnych są zmieniane. Podkreślić należy, że inne instrumenty stosuje się na w początkowych etapach procesu innowacyjnego, a inne w końcowym etapie tego procesu. Jednocześnie na przebieg procesu innowacyjnego ma z jednej strony wpływ poziomu innowacyjności społeczeństwa, a ale z drugiej - realizowana polityka innowacyjna, a zwłaszcza stosowane instrumenty jej wdrażania, w tym instrumenty określające współdziałanie w tym zakresie zainteresowanych interesariuszy (Srrrensen i Torfing, 2012).

Procesy innowacyjne dotyczą wszystkich sfer życia społeczno-gospodarczego, natomiast w niniejszym artykule będą one rozpatrywane w odniesieniu do agrobiznesu jako całości, ale z uwzględnieniem jego specyfiki. Agrobiznes obejmuje następujące ogniwa: produkcję rolniczą, przetwórstwo rolno-spożywcze, przechowywanie i logistykę oraz sprzedaż produktów rolnych i żywności, a także produkcję maszyn i urządzeń dla rolnictwa i przemysłu spożywczego (Woś, 1996; Akridge i inni, 2012).

\section{Potrzeby innowacyjne agrobiznesu i ich uwarunkowania}

Potrzeba jest to stan (lub proces, w którym stan ten występuje) braku czegoś i zarazem uruchamiający funkcję motywu do działania w kierunku odpowiedniej zmiany tego stanu (Jaskanis i Majczyk, 2016). Potrzeba innowacyjna jest to stan odczuwania braku, albo też niedostatecznej lub nieprawidłowej realizacji, wywołujący pragnienie zmian i wprowadzenia nowych rozwiązań technologicznych i organizacyjnych. Potrzeby innowacyjne w agrobiznesie dotyczą lub mogą dotyczyć każdego jego ogniwa, zmieniając dotychczasowe procesy produkcji, przechowywani i dostarczania żywności. Przykładowe obszary zmian, to:

- zmiany technologii produkcji oraz metod wytwarzania,

- zmiany w procesie przechowywania produktów żywnościowych, 
- zmiany w procesie transportu produktów żywnościowych,

- zmiany struktury produkcji,

- zmiany w zasobach czynników wytwórczych,

- zmiany dotyczące ochrony środowiska przyrodniczego,

- zmiany w organizacji pracy i zarządzania itd.

Z czego wynikają potrzeby wymienionych zmian? Są one następstwem odczuwania określonych braków $\mathrm{w}$ tym zakresie bezpośrednio przez pracujących $\mathrm{w}$ agrobiznesie, ale też $\mathrm{z}$ pobudzania $\mathrm{z}$ zewnątrz - przez politykę innowacyjną prowadzoną przez państwo i samorządy terytorialne.

Potrzeby innowacyjne osób pracujących w agrobiznesie mają różny charakter:

- indywidualny, związany bezpośrednio z podmiotem gospodarczym i prowadzoną działalnością,

- społeczny, związany z oddziaływaniem edukacji, polityki społeczeństwa, itp., na zachowania produkcyjne i innowacyjne osób pracujących w agrobiznesie, zwłaszcza zarządzających danym podmiotem,

- mieszany, uwzględniający zarówno indywidualne, jak i społeczne przesłanki wprowadzania innowacji.

Indywidualne przesłanki wprowadzenia innowacji, to przede wszystkim racjonalizowanie prowadzenia działalności oraz wprowadzenie zmian, które prowadzą do poprawy wykorzystania zasobów wytwórczych. W rezultacie jest możliwa poprawa efektywności gospodarowania i zwiększenie nadwyżki ekonomicznej. Na zmiany te może wpływać niepełne zaspokojenia potrzeb klientów, a wraz z tym chęć zwiększenia poziomu produkcji, a czasem także jej struktury. Dodatkowo zmiany te mogą wynikać z dążenia przedsiębiorców do poprawy konkurencyjności swoich produktów, czy ograniczenia siły konkurentów (Decyk i Juchniewicz, 2013; Barska, 2017). We wszystkich tych przypadkach motyw ekonomiczny jest podstawą wprowadzenia zmian technologicznych i organizacyjnych. Działania te jeśli udadzą się, to prowadzą do zwiększenia siły konkurencyjnej podmiotów oraz osiąganych dochodów (czy też zysków), ale działania te mogą być ryzykowne i prowadzić nawet do bankructwa. Wszystko to zależy od wielkości przedsięwzięcia, jego kosztów i czasu realizacji, ale także od posiadanych środków i siły konkurentów. Podkreślić należy, że motyw ekonomiczny wprowadzania innowacji jest właściwym wyborem prowadzenia działalności i czynnikiem zmian, pod warunkiem że nie prowadzi do negatywnych następstw $\mathrm{w}$ całym łańcuchu żywnościowym, ani też w środowisku przyrodniczym. Negatywne następstwa mają różny charakter, np. dotyczący pogorszenia jakości produktów żywnościowych, czy też powodujący degradację środowiska przyrodniczego. $\mathrm{W}$ tych przypadkach jest potrzeba interwencji państwa.

Motywy społeczne wprowadzania innowacji w agrobiznesie mają różny charakter, Biorą one pod uwagę różne aspekty i wynikają ze zróżnicowanych oddziaływań, m. in. takich jak:

- zaspokojenie potrzeb żywnościowych,

- jakość produkcji, w tym jej aspekt zdrowotny,

- sposób gospodarowania i technologie oszczędzające środowisko przyrodnicze,

- poprawa sytuacji dochodowej określonej grupy społecznej, np. rolników.

Przyjęcie określonych motywów społecznych znajduje odzwierciedlenie w polityce innowacyjnej $\mathrm{i}$ instrumentach ich wdrażania. Instrumenty te powinny zachęcać 
przedsiębiorców do wprowadzania określonego rodzaju innowacji, czyniąc pożądane rozwiązania jako priorytetowe. Oddziaływanie może dotyczyć też jednocześnie i konsumentów produktów żywnościowych. I tak np. zaspokojenie potrzeb żywnościowych to $\mathrm{z}$ jednej strony zwiększenie podaży produktów, $\mathrm{w}$ tym wynikających $\mathrm{z}$ wprowadzenia innowacji i rozszerzania listy produktów żywnościowych, a z drugiej może być następstwem oddziaływania na zmianę koszyka konsumpcji ze względów zdrowotnych. Niezależnie jednak od motywów tych zmian następuje wprowadzenie innowacji i to ściśle określonych (Barska, 2017). Uwzględnić trzeba, że nowe produkty żywnościowe podlegają ocenie bezpieczeństwa i dopuszczenia jej do obrotu zgodnie z ustawa o bezpieczeństwie żywności i żywienia (Ustawa, 2006).

Mieszane przesłanki wprowadzania innowacji w agrobiznesie występują wtedy, gdy pracujący $\mathrm{w}$ tym sektorze dostrzegają sygnały kierowane przez politykę społecznoekonomiczną, w tym politykę innowacyjną, a jednocześnie mają świadomość odpowiedniego ich wprowadzania i znają zagrożenia niewłaściwego ich wdrażania. W większości tak jest, że przesłanki mają charakter mieszany. Uwzględnić też należy, że motywy indywidualne wprowadzenia innowacji mogą mieć także charakter społeczny od samego początku i to nawet wcześniej niż zaczął to widzieć sektor publiczny. $Z$ taką sytuacją mamy do czynienia przede wszystkim wtedy, gdy zatrudnieni charakteryzują się wysokim poziomem wiedzy i odpowiedzialności społecznej.

\section{Kierunki wspierania innowacyjności w agrobiznesie przez politykę Unii Europejskiej}

Innowacje są podstawą funkcjonowania gospodarki unijnej. Podkreślają te kolejne programy jej rozwoju, w tym aktualne, wynikające z Programu EUROPA 2020 - Strategii na rzecz inteligentnego o zrównoważonego rozwoju sprzyjającego wtaczeniu społecznemu (Wiatrak, 2016a). Narzędziami wprowadzania tych zamierzeń są Unia Innowacji i Europejskie Partnerstwa Innowacji², które poprzez współpracę różnych podmiotów publicznych, społecznych i prywatnych podejmują działania na rzecz realizacji innowacji przeciwdziałających negatywnym skutkom dotychczasowej działalności, zwłaszcza w sferze gospodarczej (UE, 2010a, 2010b i 2010c).

Jednym z obszarów priorytetowych, wspierania jest agrobiznes, który aby zapewnić zaopatrzenie w żywność powinien mniej zużywać wody i energii ze źródeł kopalnych, a także nawozów mineralnych i środków ochrony roślin, a jednocześnie lepiej wykorzystywać komplementarność upraw i chowu zwierząt, gospodarkę odpadami organicznymi, wytwarzanie energii odnawialnej itp. Przyjmuje się, że ,...przeobrażenie działalności sektora rolnego, konieczne ze względu na coraz bardziej naglącą potrzebę efektywnego gospodarowania zasobami, przyniesie przede wszystkim wzrost produkcji żywności przy zastosowaniu bardziej zrównoważonych metod, ale także dostarczy szeregu różnych usług na rzecz społeczeństwa oraz bioproduktów związanych ze zdrowiem, wypoczynkiem, zagospodarowaniem przestrzennym, gospodarowaniem odpadami, gospodarką paszową, włóknami i energią odnawialną" (UE, 2013). W tym celu powstał program innowacyjnego partnerstwa na rzecz wydajnego i zrównoważonego rolnictwa, którego działania są nakierowane głównie na (UE, 2012):

${ }^{2}$ EIP - European Innovation Partnerships. 
1. Większą wydajność, produkcję i bardziej efektywne gospodarowanie zasobami w rolnictwie, które będą oszczędzały zasoby i środowisko (zwłaszcza zasoby naturalne), ograniczały straty w produkcji rolniczej i wykorzystywały postęp biologiczny;

2. Innowacje wspierające gospodarkę ekologiczną w całym łańcuchu wytwarzania i dostarczania żywności poprzez wspieranie technologii ekologicznych, np. zintegrowaną biologiczną ochronę roślin, zmniejszenie emisji gazów cieplarnianych, wykorzystanie biomasy, biofermentację, biorafinerię, recykling itp.;

3. Różnorodność biologiczną, usługi ekosystemowe oraz funkcjonalność gleb poprzez lepsze gospodarowanie gruntami, zintegrowane systemy rolno-ekologiczne, stosowanie naturalnych metod ochrony ekosystemów itp.;

4. Opracowanie i wykorzystanie innowacyjnych produktów, urządzeń i usług oraz stworzenie zrównoważonego i sprawnie zarządzanego łańcucha dostaw żywności;

5. Jakość żywności, bezpieczeństwo żywności i zdrowy styl życia - z jednej strony prowadzone przez działania wymienione $\mathrm{w}$ poprzednich punktach, $\mathrm{z}$ drugiej zaś poprzez informację i edukację w tym zakresie.

Podjęte działania mają różny charakter, ale łączy je podejście innowacyjne, propagujące zrównoważone gospodarowanie $\mathrm{W}$ agrobiznesie $\mathrm{W}$ połączeniu $\mathrm{z}$ wykorzystaniem biologicznych i ekologicznych czynników rozwoju. Jednocześnie zwraca się uwagę na lepsze wykorzystanie organizacyjnych czynników rozwoju poprzez systemy zarządzania produkcją i jej dystrybucją oraz sprawny system informacji i monitorowania, który umożliwia integrowanie poszczególnych ogniw łańcucha żywnościowego. Organizacyjne czynniki rozwoju i wdrażania innowacji w agrobiznesie to także współpraca i współdziałanie, $\mathrm{m}$. in. na szczeblu lokalnym i regionalnym, gdzie są największe możliwości dynamiki gospodarczej i społecznej (Wiatrak, 2016b). Tam bowiem znajdują się zasoby wytwórcze, a przede wszystkimi zasoby ludzkie, które decydują o rozwoju. W związku z tym dobrze byłoby wyakcentować istniejące możliwości rozwoju i inwestowania, dostosować rozmiary i sposób prowadzenia działalności (do posiadanych zasobów wytwórczych i preferowanych metod gospodarowania (np. poprzez stosowanie technologii przyjaznych środowisku), a także zmotywować społeczność do ich zastosowania. Uwzględnić należy, że sprawy żywności i wyżywienia należą do podstawowych, dlatego też ważny jest konsensus w zakresie kierunków rozwoju. Narzędziami tych działań i realizacji mogą być m.in. krajowe inteligentne specjalizacje (KIS) i regionalne inteligentne specjalizacje (RIS3), które są skierowane na określony obszar i jego zasoby, w tym na zasoby specyficzne i marginalne (Foray, 2009). Jednocześnie strategie inteligentnej specjalizacji - jako preferowany sposób działania mogą zarówno stymulować inwestycje prywatne, jak i sprzyjać efektywniejszemu oraz sprawniejszemu wykorzystaniu funduszy publicznych, w tym funduszy pomocowych w poszczególnych krajach i regionach. „Zamiast rozdrabniać inwestycje w różnych obszarach i branżach, z ich pomocą regiony skoncentrują zasoby na kilku kluczowych priorytetach. Mogą one również stanowić podstawowy element rozwoju wielopoziomowego zarządzania w kontekście zintegrowanej polityki innowacji. Ponadto muszą być ściśle związane $\mathrm{z}$ innymi obszarami polityki i wymagają zrozumienia mocnych stron regionu $\mathrm{w}$ porównaniu $\mathrm{z}$ innymi oraz ewentualnych korzyści dla współpracy międzyregionalnej i międzynarodowej” (UE, 2010c). 


\section{Kierunki wspierania innowacyjności w agrobiznesie przez politykę w Polsce}

Polityka innowacyjna UE przekłada się na polityki krajów członkowskich, jest wytyczną jej kierunków i zwróceniem uwagi na określone zagadnienia. Ogólne jej zalecenia są podobne do wszystkich krajów członkowskich, ale szczegółowe rozwiązania zróżnicowane, gdyż potrzeby innowacyjne w poszczególnych krajach są także zróżnicowane. Wynika to $\mathrm{z}$ różnego poziomu rozwoju agrobiznesu, stosowania różnych technologii produkcji, zróżnicowanego stopnia innowacyjności agrobiznesu i całej gospodarki itd.

Wstąpienie Polski do Unii Europejskiej wymusiło wiele zmian w agrobiznesie i zmiany te nadal są kontynuowane. Wynikają one $\mathrm{z}$ programów realizowanych $\mathrm{w}$ kolejnych perspektywach finansowych, w tym obecnej, w której zagadnienia innowacyjności są najszerzej ujęte. W odniesieniu do agrobiznesu w Polsce znajdują się one w Programie Rozwoju Obszarów Wiejskich na lata 2014-2020, który określa kierunki działań innowacyjnych i sposoby ich realizacji w poszczególnych jego ogniwach (por. GoryńskaGoldmann i Wojcieszak, 2017), wskazując na niski poziom innowacyjności sektora rolnego, który „...znacznie odstaje od innych sektorów gospodarki (...), co znajduje odzwierciedlenie w takich wskaźnikach jak: produktywność pracy i ziemi, udział nakładów na środki trwałe, średnia wieku i poziom wykształcenia rolników oraz dostęp do Internetu na obszarach wiejskich. Niska jest także innowacyjność polskiego przemysłu spożywczego, o czym świadczy m.in. niewielki udział nakładów na działalność innowacyjną w wartości dodanej sprzedaży, dominacja wydatków na zakup środków trwałych w strukturze nakładów na działalność innowacyjną, małe zainteresowanie nabywaniem nowej wiedzy oraz wprowadzaniem na rynek nowych wyrobów. Niewystarczające są także powiązania między sektorem nauki a rolnictwem" (Program, 2017).

Prezentowana ocena miała wpływ na wyznaczenie celów rozwoju obszarów wiejskich i agrobiznesu, które uwzględniają wytyczne unijne i poziom rozwoju tego sektora oraz potrzeby w tym zakresie. Cele priorytetowe rozwoju obszarów wiejskich, ale też i rolnictwa i pozostałych ogniw agrobiznesu na lata 2014-2020 określono następująco (Program, 2017):

- Zwiększenie liczby konkurencyjnych gospodarstw rolnych;

- Reorientacja małych gospodarstw w kierunku rolniczym lub pozarolniczym;

- Zapewnienie trwałości rolnictwa w obliczu zmian klimatu i naturalnych ograniczeń oraz ochrona i poprawa stanu wód gruntowych;

- Poprawa zbytu produktów rolnych i wzmocnienie pozycji rolników w łańcuchu żywnościowym;

- Poprawa jakości produktów rolnych i żywnościowych;

- Odtwarzanie i zachowanie różnorodności biologicznej, w tym na obszarach NATURA 2000 i obszarach o utrudnieniach naturalnych;

- Promowanie zrównoważonych metod gospodarowania: rolnictwo zrównoważone i rolnictwo ekologiczne;

- Zachowanie zasobów genetycznych roślin uprawnych oraz zwierząt gospodarskich;

- Tworzenie możliwości zatrudnienia poza rolnictwem bez zmiany miejsca zamieszkania.

- Rozwój infrastruktury technicznej i społecznej na obszarach wiejskich;

- Aktywizacja mieszkańców obszarów wiejskich i wykorzystanie potencjałów endogenicznych na rzecz rozwoju lokalnego; 
- Wzrost innowacyjności, unowocześnienie sektora rolno-spożywczego oraz podniesienie poziomu wiedzy producentów rolnych.

W zestawie wyznaczonych celów, tylko jeden bezpośrednio dotyczy innowacyjności, w którym szerzej nakreślono kierunki działań innowacyjnych w agrobiznesie, ale realizacja pozostałych celów także wymaga zastosowania innowacji. I tak np. zapewnienie trwałości rolnictwa w obliczu zmian klimatu i naturalnych ograniczeń oraz ochrona i poprawa stanu wód gruntowych jest możliwa, gdy będą realizowane innowacje w tym zakresie. Rozwiązania innowacyjne będą sprzyjać dostosowaniu działalności w agrobiznesie do potrzeb środowiska. Tak samo poprawa jakości produktów rolnych i żywnościowych, poprawa zbytu produktów rolnych, wzmocnienie pozycji rolników w łańcuchu żywnościowym itd. łączy się z innowacjami i działaniami na rzecz ich wdrażania. Podkreślić należy, że te działania obejmują nie tylko bezpośrednio wprowadzane innowacje, ale nastawione są na tworzenie warunków do ich realizacji. Efektywność wdrażania Programu i jego poszczególnych celów jest uzależniona od poziomu wiedzy zatrudnionych w agrobiznesie - poczynając od producentów rolnych, a kończąc na doradcach pracujących na rzecz rolnictwa i pozostałych ogniw sektora rolno-spożywczego oraz obszarów wiejskich. „Ograniczenia mogą dotyczyć wiedzy specjalistycznej i kapitału niezbędnego do opracowania i wdrożenia nowego rozwiązania" (Program, 2017), w tym kapitału intelektualnego. Podkreślić należy, że czynnik wiedzy może być rozstrzygający i określający powodzenie $\mathrm{w}$ wdrożeniu programów i projektów innowacyjnych $\mathrm{w}$ agrobiznesie.

Na podstawie poszczególnych zapisów w kolejnych częściach PROW 2014-2020 można wskazać na następujące kierunki działań innowacyjnych w polskim agrobiznesie (Program 2017):

1. Zwiększenia nakładów na działalność badawczo-rozwojową, w tym dotyczących rozwiązań przyjaznych dla środowiska i klimatu;

2. Podniesienie kwalifikacji zatrudnionych, zwłaszcza w rolnictwie oraz ich świadomości dotyczących nowych metod produkcji, w tym oszczędzających środowisko;

3. Podniesienie kompetencji doradców, którzy powinni odegrać większą rolę w rozpowszechnianiu innowacji.

4. Powstanie grup operacyjnych na rzecz innowacji (partnerstwa EPI);

5. Wzmocnienie mechanizmów transferu informacji, wiedzy i innowacji;

6. Wsparcie inwestycji $\mathrm{w}$ agrobiznesie $\mathrm{i}$ infrastrukturze agrobiznesu, które będą realizowały konkretne procesy innowacyjne, np. nowoczesne technologie w przetwórstwie;

7. Rozwój krajowych i regionalnych inteligentnych specjalizacji.

Wymienione kierunki działań innowacyjnych potwierdzają, że polityka rolna i wiejska jest nastawiona na tworzenie warunków dla rozwoju i wdrażania innowacji. Podstawą tych działań jest wiedza i przygotowanie się do zmian. Jednocześnie stawia się na współpracę agrobiznesu z placówkami naukowo-badawczymi, aby wspólnie wypracować innowacje, które będą najbardziej odpowiednie do wdrożenia. Aby ułatwić tę współpracę powstała „Sieć na rzecz innowacji w rolnictwie i na obszarach wiejskich", której cele określono następująco:

- „ułatwianie tworzenia oraz funkcjonowania sieci kontaktów pomiędzy rolnikami, podmiotami doradczymi, jednostkami naukowymi, przedsiębiorcami sektora rolnospożywczego oraz pozostałymi podmiotami wspierającymi wdrażanie innowacji w rolnictwie i na obszarach wiejskich,

- ułatwianie wymiany wiedzy fachowej oraz dobrych praktyk w zakresie innowacji w rolnictwie i na obszarach wiejskich, 
- $\quad$ pomoc $\mathrm{w}$ tworzeniu grup operacyjnych na rzecz innowacji oraz pomoc w opracowaniu projektów przez grupy operacyjne i partnerstwa na rzecz innowacji” (SIR, 2017).

Zakłada się, że w działaniach na rzecz innowacji w agrobiznesie podstawową rolę będą mieli doradcy, dla których przewiduje się nie tylko pomoc doradczą dotyczącą podjęcia działalności innowacyjnej i jej wdrożenia, ale także pośrednika, który będzie wskazywał na możliwe do wdrożenia innowacje, pomagał w wymianie innowacyjnych rozwiązań wdrożonych w agrobiznesie, wskazywał na potrzebę określonych badań dla jego potrzeb itd. Proponuje się, aby doradca pełnił rolę brokera innowacji, tj. podmiotu łączącego współpracę w obszarze innowacji pomiędzy podmiotami sektora rolno-spożywczego, naukowobadawczego i doradztwem (Program, 2017; Wiatrak, 2016b). Można dyskutować, czy rolę brokera powinien pełnić tylko doradca, czy też inne osoby. W moim przekonaniu rolę taką mogą pełnić nie tylko doradcy, ale też przedstawiciele jednostek naukowo-badawczych (w tym uczelni), którzy w pracy badawczej zajmują się zagadnieniem będącym zakresem działania powstałej grupy operacyjnej. Widziałbym taki wybór ze względu na to, że badacze dobrze znają daną problematykę, mogą udzielać porad z jej zakresu, jak też być inicjatorem zmian, natomiast doradcy często dopiero poznawaliby te zagadnienia.

W PROW 2014-2020 wskazuje się na potrzebę badań i ich rozwijania, jako źródła innowacji w agrobiznesie. Jednocześnie podkreśla się, że dotychczasowy model wdrażania innowacji nie jest właściwy, gdyż dominuje podażowy model rozpowszechniania rozwiązań przez jednostki naukowo-badawcze, a przygotowana oferta często nie odpowiada istniejącemu zapotrzebowaniu. W związku z tym proponuje się sieć innowacji rolniczych i grupy operacyjne na rzecz innowacji, w których podstawową rolę ma doradca działający jako broker. Uwzględnić tutaj należy, że rolą brokera jest zbieranie informacji na temat innowacji potrzebnych i wdrożonych, potrzeb w tym zakresie, powstałych rozwiązań i ich doskonalenia itd. (Program, 2017). Niezależnie jednak kto będzie brokerem, to rozwijanie współpracy pomiędzy poszczególnymi ogniwami agrobiznesu i sektorem wiedzy powinno zaowocować nowymi rozwiązaniami i sprzyjać zwiększeniu liczby wdrażanych innowacji. W rezultacie powinno to prowadzić do zwiększenia konkurencyjność agrobiznesu, ale też i do poprawy sytuacji ekonomicznej podmiotów uczestniczących w partnerstwie.

Kierunki innowacji w agrobiznesie wyznaczają też krajowe i regionalne inteligentne specjalizacje. W Polsce w odniesieniu do agrobiznesu zbiorczą krajową inteligentna specjalizację określono jako: Biogospodarka rolno-spożywcza, leśno-drzewna i środowiskowa, a w ramach niej wyodrębniono trzy następujące (KIS, 2015):

KIS 4. Innowacyjne technologie, procesy i produkty sektora rolno-spożywczego i leśnodrzewnego;

KIS 5. Zdrowa żywność (o wysokiej jakości i ekologiczności produkcji);

KIS 6. Biotechnologiczne procesy i produkty chemii specjalistycznej oraz inżynierii. środowiska

W poszczególnych specjalizacjach zostały wyodrębnione grupy i podgrupy, które charakteryzują ich zakres, jak np. innowacyjne technologie i maszyny dla rolnictwa i przetwórstwa, w tym energooszczędne i sprzyjające ochronie środowiska. Jednocześnie opracowano inteligentne specjalizacje na poziomie województw, które w dużym stopniu są zbieżne z krajowymi (por. Gołębiewski, 2014). Analizując grupy i podgrupy KIS i RIS3 można zastanowić się, czy mają one charakter inteligentny. Mam wątpliwości ze względu na szerokie ich ujęcie, natomiast inteligentne powinny mieć charakter dobra rzadkiego. 


\section{Podsumowanie}

Z przeprowadzonych rozważań wynika, że innowacyjność należy rozpatrywać szeroko, biorąc pod uwagę dotychczasowy poziom innowacyjności, potrzeby w zakresie innowacji, proces innowacyjny i jego uwarunkowania. Analizując te zagadnienia należy uwzględnić:

1. Opracowanie polityki innowacyjnej i narzędzi jej wdrażania, która bierze pod uwagę potrzeby w zakresie innowacji i istniejące uwarunkowania ich realizacji. Szczególnie należy zwrócić uwagę na narzędzia realizacji innowacji, w tym oddziaływania na wzrost kwalifikacji i umiejętności zatrudnionych w agrobiznesie, od których zależy w dużym stopniu uruchomienie procesów innowacyjnych.

2. Powiązanie polityki innowacyjnej agrobiznesu z innymi politykami, zwłaszcza rolną, wiejską, środowiskową i regionalną itd., w tym polityką UE, aby były spójne i kompleksowo wspierały procesy zmian.

3. Współpracę poszczególnych ogniw agrobiznesu z placówkami naukowo-badawczymi, $\mathrm{w}$ celu wypracowania nowych innowacji, co jest proponowane w ramach partnerstwa grup operacyjnych.

\section{Literatura}

Akridge, J.T., Barnard, F.L., Dooley, F.J., Foltz, J.Ch. (2012). Agribusiness Management, London, Wyd. Taylor \& Francis Ltd, Part 1.

Barska, A. (2017). Innowacje na rynku produktów żywnościowych z perspektywy polskich i czeskich konsumentów generacji Y. Zeszyty Naukowe Szkoły Głównej Gospodarstwa Wiejskiego w Warszawie Problemy Rolnictwa Światowego, 17 (1), 7-18, DOI: 10.22630/PRS.2017.17.1.1

Czerniak, J. (2013). Polityka innowacyjna w Polsce. Analiza i proponowane kierunki zmian. Wyd. Difin, Warszawa.

Decyk, K., Juchniewicz, M. (2013). Działania i instrumenty polityki innowacyjnej w opinii mikroprzedsiębiorców. Zarzadzanie Publiczne, 2 (22), 237-251, DOI:10.4467/20843968ZP.13.020.1194.

Firlej, K., Makarska, A. (2012). Działania innowacyjne firm przemysłu spożywczego jako element ich strategii. Folia Pomeranae Universitatis Technologiae Steinensis, Oeconomica, 297 (68), 37-46.

Foray, D. (2009). Understanding Smart Specialization. W: Pontikakis, D., Kyriakou, D., van Bavel, R. (red.) The Questions of R\&D Specialization: Perspectives and Policy Implications. Institute for Perspective Technological Studies - Joint Research Centre, Seville, 19-28.

Gołębiewski, J. (2014). Biogospodarka jako inteligenta specjalizacja regionów w Polsce. Przedsiębiorczość i Zarzadzanie, 15 (8-1), 55-69.

Goryńska-Goldmann, E., Wojcieszak, M. (2017). Program Rozwoju Obszarów Wiejskich 2014-2020 jako źródło podnoszenia innowacyjności. Roczniki Naukowe Stowarzyszenia Ekonomistów Rolnych i Agrobiznesu, 19 (1), 44-51, DOI: $10.5604 / 01.3001 .0009 .8338$.

Jasiński, A.H. (2014). Innowacyjność w gospodarce Polski. Modele, bariery, instrumenty wsparcia. Wyd. Naukowe Wydziału Zarządzania Uniwersytetu Warszawskiego, Warszawa.

Jaskanis, A., Majczyk, J. (2016). Nurt Human Relations i zachowania organizacyjne. W: Zarzadzanie, organizacje i organizowanie. Przegląd perspektyw teoretycznych. Wyd. Naukowe Wydziału Zarządzania Uniwersytetu Warszawskiego, Warszawa, 389-403.

KIS (2015). Krajowe inteligentne specjalizacje, Ministerstwo Gospodarki, Warszawa.

Klincewicz, K. (2011). Dyfuzja innowacji. Jak odnieść sukces w komercjalizacji nowych produktów i usług. Wyd. Naukowe Wydziału Zarządzania Uniwersytetu Warszawskiego, Warszawa.

OECD (2005). Oslo Manual, Guidelines for Collecting and Interpreting Innovation Data, OECD and Eurostat, Oslo. Program Rozwoju Obszarów Wiejskich na lata 2014-2020. Ministerstwo Rolnictwa i Rozwoju Wsi, Warszawa. Pobrane 1 czerwca 2017 r. z https://www.minrol.gov.pl/Wsparcie-rolnictwa/Program-Rozwoju-ObszarowWiejskich-2014-2020.

SIR (2017). Sieć na rzecz innowacji w rolnictwie i na obszarach wiejskich. Centrum Doradztwa Rolniczego, Brwinów. Pobrane 1 czerwca 2017 r. z http://www.cdr.gov.pl sir/90-nasze-dzialania/sir/sir-schemat/1744czym-jest-sir. 
Srrrensen, E., Torfing J. (2012). Introduction Collaborative Innovation in the Public Sector. The Innovation Journal: The Public Sector Innovation Journal, 17(1), 1-14.

UE (2010a). Europa 2020 - Strategia na rzecz inteligentnego i zrównoważonego rozwoju sprzyjającego włączeniu społecznemu, Komisja Europejska, KOM (2010) 2020, wersja ostateczna.

UE (2010b). Komunikat Komisji do Parlamentu Europejskiego, Rady, Europejskiego Komitetu EkonomicznoSpołecznego oraz Komitetu Regionów z dnia 6 października 2010 r. - Projekt przewodni strategii Europa 2020 - Unia innowacji, $\operatorname{COM}(2010) 546$ wersja ostateczna.

UE (2010c). Polityka regionalna jako czynnik przyczyniający się do inteligentnego rozwoju w ramach strategii Europa 2020, Komunikat Komisji do Parlamentu Europejskiego, Rady Europejskiego Komitetu Ekonomiczno-Społecznego i Komitetów Regionów z dnia 6 października 2010, KOM (2010) 553, wersja ostateczna.

UE (2012). Komunikat Komisji do Parlamentu i Rady w sprawie europejskiego partnerstwa innowacyjnego na rzecz wydajnego i zrównoważonego rozwoju z dnia 29 lutego 2012, Komisja Europejska EUR-Lex, COM 79, wersja ostateczna.

UE (2013). Opinia Komitetu Regionów Europejskie partnerstwo innowacyjne na rzecz wydajnego i zrównoważonego rolnictwa z dnia 10 stycznia 2013, Dziennik Urzędowy Unii Europejskiej (2013/C 17/10.

Ustawa z dnia 25 sierpnia 2006 r. o bezpieczeństwie żywności i żywienia, Dz. U. 2006, nr 171, poz.1225, tekst ujednolicony z 31.01.2017 r. Pobrane 15 maja 2017 r. z http://isip.sejm.gov.pl/prawo/index.html.

Wiatrak, A.P. (2016a). Innowacyjność w politykach Unii Europejskiej i ich wpływ na kierunki wspierania organizacji. Zarzadzanie i Finanse, 14 (2-2), 463-472.

Wiatrak, A.P. (2016b). Sieć innowacji w rolnictwie - istota, cele i uwarunkowania. Roczniki Naukowe Stowarzyszenia Ekonomistów Rolnictwa i Agrobiznesu, 18 (3), 380-384

Woś, A. (1996). Agrobiznes. Makroekonomika, Wyd. Key Text, Warszawa. 